\title{
The avifauna of the Río Machariapo dry forest, northern La Paz department, Bolivia: a preliminary investigation
}

\author{
MARK PEARMAN
}

\begin{abstract}
Summary
In March 1993, a survey of dry forest along the Río Machariapo, northern La Paz department, Bolivia, resulted in seven new bird species for the department, including some range extensions of several hundred kilometres: Coccyzus erythropthalmus, Otus guatemalae, Poecilurus scutatus, Formicivora melanogaster, Empidonax traillii alnorum, Nemosia pileata and Conirostrum speciosum. A probable new Herpsilochmus antwren was collected. These discoveries are of high conservation interest, especially as the La Paz - Cobija road is to be constructed through the Machariapo Valley, with work resuming in May 1993 and already very close to the head of the valley. Thus several new plant and bird taxa may be lost through deforestation even before they can be described.
\end{abstract}

Un estudio del bosque seco a lo largo del Río Machariapo en el norte del Departamento de La Paz, Bolivia, realizado en marzo de 1993, trajo como resultado el descubrimiento de siete nuevas especies de aves en este departamento, incluyendo algunas ampliaciones, de unos cien kilómetros, del área de distribución conocida: Coccyzus erythropthalmus, Otus guatemalae, Poecilurus scutatus, Formicivora melanogaster, Empidonax traillii alnorum, Nemosia pileata y Conirostrum speciosum. También se recolectó un Herpsilochmus sp. que es probablemente una nueva especie. Estos nuevas descubrimientos son de alto interés para la conservación, especialmente porque se está construyendo una carretera desde La Paz a Cobija por el Valle Machariapo. La construcción va a continuar en mayo de 1993 y actualmente esta se encuentra muy cerca del principio del valle. De esta manera nuevos taxa de plantas y aves podrian desaparecer a causa de deforestación, incluso antes de que se pudieran describir totalmente.

\section{Introduction}

The lower eastern slope of the Andes in Peru have, in the past three decades, been the focus of considerable ornithological field survey work in which many new bird taxa were discovered (e.g. Lowery and $\mathrm{O}^{\prime}$ Neill 1964, Fitzpatrick and $\mathrm{O}^{\prime}$ Neill 1979, Fitzpatrick et al. 1979, Schulenberg and Binford 1985, Davis and $\mathrm{O}^{\prime}$ Neill 1986, Graves and Weske 1987). The corresponding Andean slope and adjacent Amazonian lowlands in northern Bolivia have, in contrast, been subject to little investigation, although recently the gathering consensus is that an estimated $11 \%$ of the world's bird species may be present in La Paz department (see Parker and Bailey 1991).

A botanical and zoological survey of the Rio Machariapo, northern La Paz department, Bolivia, took place in 1990, during which tape-recordings were made by non-ornithologists for later identification by T. A. Parker (Parker and 
Bailey 1991). Prompted by the initial findings of this study, from 13 to 19 March 1993 I surveyed intensively a $3 \mathrm{~km}^{2}$ mid-elevation section of the valley at c. 1,000 $\mathrm{m}$ altitude (see Figure 1) at Estancia San Isidro de Paquicha (14 $33^{\prime} \mathrm{S} 68^{\circ} 35^{\prime} \mathrm{W}$ ). Additional observations were made along the valley at $900-1,200 \mathrm{~m}$ and on the Apolo plateau from Apolo (14 $\left.43^{\prime} \mathrm{S} 68^{\circ} 31^{\prime} \mathrm{W}\right)$ to Vilipiza $\left(14^{\circ} 39^{\prime} \mathrm{S} 68^{\circ} 32^{\prime} \mathrm{W}\right)$, at the head of the Río Machariapo valley, on 12-13 and 19-20 March 1993.

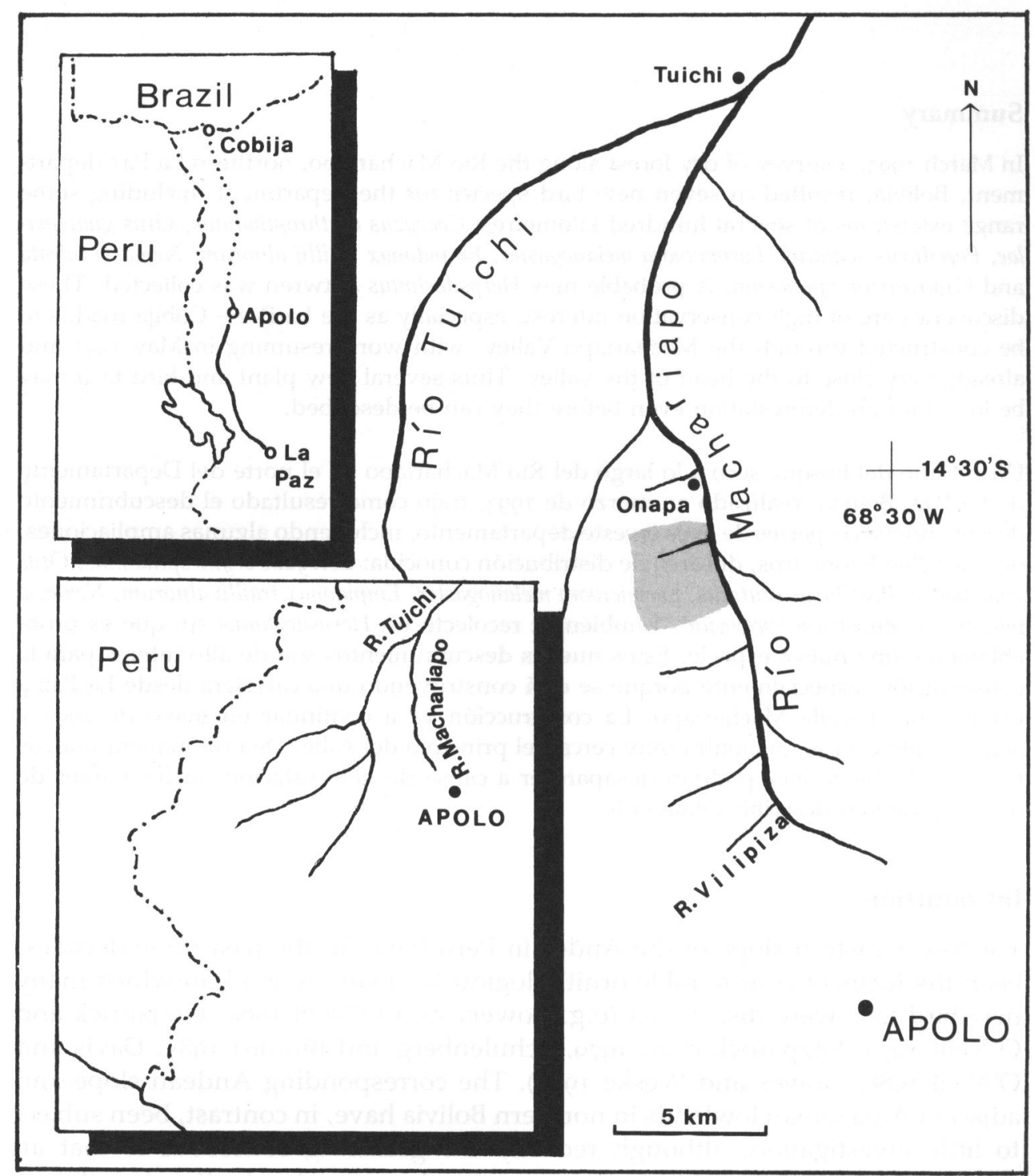

Figure 1. Main map showing Río Machariapo and its tributaries, Onapa and Tuichi villages, and survey quadrant (shaded area) in Estancia San Isidro de Paquicha. Lower inset: geographical position of the Machariapo and Tuichi drainage. Upper inset: La Paz to Cobija road; constructed (solid black line) and planned (dotted line). 


\section{Physiography and vegetation}

The headwaters of the Rio Machariapo lie $11 \mathrm{~km}$ north-north-west of Apolo in the province of Franz Tamayo, La Paz department, at $14^{\circ} 37^{\prime} \mathrm{S} 68^{\circ} 32^{\prime} \mathrm{W}$, the river flowing C. $35 \mathrm{~km}$ north-north-west where it drains into the Río Tuichi at $14^{\circ} 18^{\prime} \mathrm{S}$ $68^{\circ} 35^{\prime} \mathrm{W}$. Altitudes are from 1,200 $\mathrm{m}$ at Vilipiza, the head of the valley, to $700 \mathrm{~m}$ at Tuichi (see Figure 1), thus corresponding to the upper tropical climatic zone. The valley is broad (c. 3-5 km across), with steeply rising sides to bare open grassy plateaus, and is essentially walled-in (see Figure 2). The underlying rock is geologically mapped as of Devonian age and is radically different from the Ordovician age rock at Apolo (Parker and Bailey 1991).

A. H. Gentry and R. B. Foster (in Parker and Bailey 1991) confirmed the presence of many typical dry forest features such as low plant diversity, prevalence of legume trees, bignon vines, and numerous species of Cactaceae and Capparidaceae. Two lianas, previously known from eastern Paraguay and southern Brazil, the American staghorn fern Platycerium andinum, until now considered endemic to central Peru, and two dominant cacti were all new records for Bolivia, the cacti possibly representing undescribed taxa endemic to the valley.

A small proportion of the floodplain has been developed for agricultural purposes, mainly with rice paddies, and coffee and mandarin plantations, although some of these are now abandoned and overgrown. Some natural subsidence has occurred in the upper valley (see Figure 2). Foster and Gentry (in Parker and Bailey 1991) hypothesized that, owing to previous forest cutting, the completely deciduous character of the valley must be seen as an artefact of human influence and that, left to itself, it would return to a semi-deciduous character. The presence of typical dry forest bird species such as Ochre-cheeked Spinetail Poecilurus scutatus and Black-bellied Antwren Formicivora melanogaster (see below), however, would appear to indicate that the forest was always dry or has been for a considerable time-span, leaving isolated disjunct populations of these species. Generally, it appears that the valley is truly isolated and unique; the local inhabitants lack any knowledge of other dry valleys in the region.

\section{Survey methods}

The survey was conducted on foot using a Marantz $\mathrm{CP}_{43} 3$ tape-recorder and Sennheiser ME80 microphone over a total of 17 net-hours at four sites at around $1,000 \mathrm{~m}$ (see Figure 1). A number of blood samples were taken for use in DNA analysis at the Institute of Zoology, Zoological Society of London, and at the University of Copenhagen.

\section{Results}

A total of 106 bird species were encountered, 15 of which were observed only on the Apolo plateau. The dry forest along the Río Machariapo held an interesting mixture of foothill birds and other cloud-forest forms, such as Upland Antshrike Thamnophilus aroyae, Yungas Tody-tyrant Hemitriccus spodiops and 


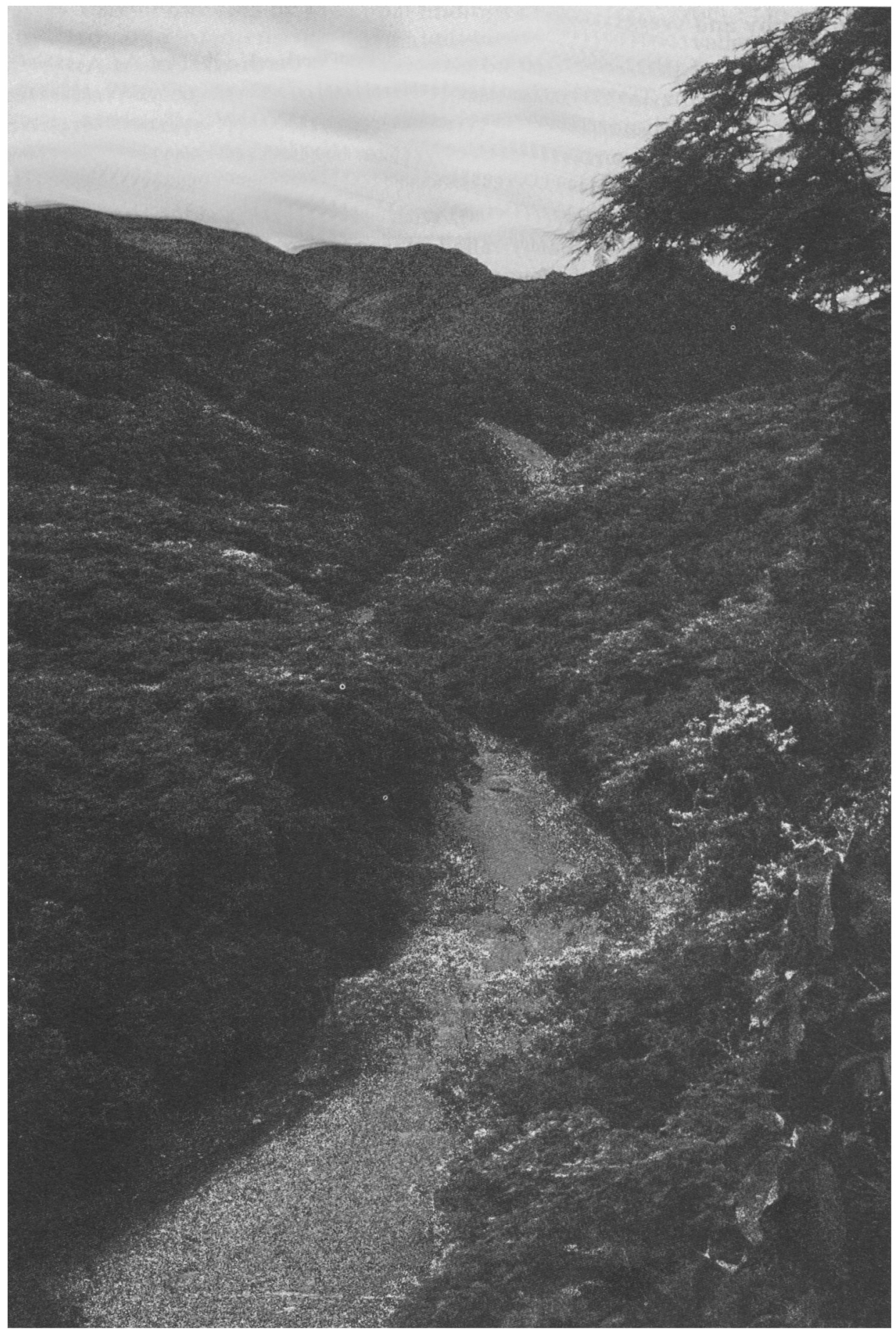

Figure 2. Dry forest along the upper reaches $(1,100 \mathrm{~m})$ of the Río Machariapo, 19 March 1993; natural subsidence visible on left bank. (Photo: M. Pearman.) 
Rough-legged Tyrannulet Phyllomyias burmeisteri (for which see Parker et al. 1991), not typically recorded from low elevation or dry forest.

More surprisingly, two species, Ochre-cheeked Spinetail and Black-bellied Antwren, typical of dry forest several hundred kilometres to the south-east in Santa Cruz department, were encountered daily and represent new department records. The presence of a Herpsilochmus sp. is also highly significant, as several allopatric forms of the genus occur elsewhere in low-elevation dry forest.

An annotated checklist (Appendix) and further details on noteworthy species records (see below) substantiate the above-mentioned range extensions and an additional five new records for the department of La Paz. While the checklist is preliminary, it should be noted that additional species will undoubtedly be encountered in future survey work.

\section{Noteworthy records}

Unless otherwise stated all records refer to dry forest in the Machariapo valley. All dates refer to March 1993.

\section{Pyrrhura sp.}

Encountered daily in groups of up to 30 individuals throughout the valley. Possibly refers to Green-cheeked Parakeet $P$. molinae, which these birds closely resembled except for the lack of the red belly patch. Two other Pyrrhura spp., Painted Parakeet $P$. picta and Black-capped Parakeet $P$. rupicola, are known from northern La Paz department, but both have distinct plumages and occur in the tropical lowland forest. However, hybrid forms of both have been collected in nearby Puno, Peru (T. S. Schulenberg in litt.) The Machariapo birds may represent a geographical variation of $P$. molinae, hybrid population or possibly an undescribed form.

\section{Black-billed Cuckoo Coccyzus erythropthalmus}

One individual was observed c. $6 \mathrm{~m}$ up, associating with a large mixed flock, at the edge of an overgrown and abandoned coffee plantation inside dry forest on 20 March. This represents the first record for La Paz department; this migrant species is otherwise known in Bolivia from the lowlands of Cochabamba and Santa Cruz departments (Remsen and Traylor 1989).

\section{Vermiculated Screech-owl Otus guatemalae}

One bird was tape-recorded high inside tall primary forest at Estancia San Isidro de Paquicha on 14 March. The voice is confirmed by Hardy et al. (1990) and represents the first record for La Paz department; the species was only previously known in Bolivia from foothills in Cochabamba department (Remsen and Traylor 1989). 


\section{Ochre-cheeked Spinetail Poecilurus scutatus}

A very common inhabitant of the understorey and often seen hopping on the forest floor; these birds were vocalizing throughout the valley. This constitutes a considerable range extension to the north and west of Santa Cruz department, where the species also typically inhabits dry forest, and is the first record for the department of La Paz.

\section{Herpsilochmus sp.}

In June 1990, L. Emmons and E. Wolf, whilst investigating mammals in the Machariapo valley, made tape-recordings of a species which T. A. Parker later identified as "appearing to be an undescribed Herpsilochmus antwren" (Parker and Bailey 1991). Parker's assumption would appear correct. This antwren was common from Vilipiza, at the head of the valley, to at least Onapa (c. $900 \mathrm{~m}$ ), and shares morphological characteristics with the Herpsilochmus pileatus complex (see Davis and $\mathrm{O}^{\prime} \mathrm{Neill}$ 1986). One male was collected (Colección Boliviana de Fauna CBF-02617) and a blood sample taken. While morphological, biometric and vocalization data indicate, at this stage, that the form represents an undescribed taxon, I await a DNA base-sequence analysis and more detailed studies before offering a technical description.

\section{Black-bellied Antwren Formicizora melanogaster}

This species was encountered commonly throughout the upper and midelevations of the valley, where it was vocal and conspicuous. Identification is confirmed by comparison of sound-recordings from Brazil, which appear identical (and discernibly different from the closely allied White-fringed Antwren $F$. grisea). The plumage of this population differs from that of other known populations of F. melanogaster by the presence of white fringes on the black throat and breast feathers, creating a slightly scaled effect. This may be a trait of geographical isolation. The range of $F$. melanogaster is extended considerably, being hitherto known in Bolivia from Santa Cruz, Chuquisaca and Tarija departments (Remsen and Traylor 1989).

\section{Traill's (Alder) Flycatcher Empidonax traillii (alnorum)}

Two individuals were trapped on 15 March at forest edge and another observed c. $2.5 \mathrm{~km}$ north-north-west of Apolo at the edge of an isolated woodlot on 19 March. As E. traillii and E. alnorum cannot yet be reliably separated by in-hand criteria alone (Pyle et al. 1987) I make no specific identification. Plumage, biometric and distributional data, however, would strongly favour E. alnorum. While these records are the first from La Paz department, the species is known in Bolivia from Pando, Beni, Cochabamba, Santa Cruz and Chuquisaca departments (Remsen and Traylor 1989); its occurrence was therefore to be expected. A voucher blood sample is held with the University of Copenhagen DNA bank. 


\section{Slate-coloured Seedeater Sporophila schistacea}

A pair were observed at the edge of a clearing at Estancia San Isidro de Paquicha on 18 March. The birds perched c. $6 \mathrm{~m}$ up at forest edge before flying across a rice paddy. While the species is not listed for La Paz department by Remsen and Traylor (1989), there exist several museum specimens and sight records (O. Rocha O. et al. in prep.).

\section{Dark-throated Seedeater Sporophila ruficollis}

A subadult male and accompanying immature bird, believed to be this species, were located c. $6 \mathrm{~km}$ north-north-west of Apolo on an open grassy hillside on 19 March. Both individuals gave the classic single-syllable Sporophila call-notes but no song was delivered. The birds were presumably on migration, taking into account the date, as S. ruficollis is one of latest breeding Sporophila species in northern Argentina (Pearman and Abadie in prep.). S. ruficollis is known to winter in the department of Beni, but this significant record, the second for La Paz department, after being recorded as rare at Ixiamas (Parker and Bailey 1991), highlights how imperfectly we understand the wintering range of the species. The implication is that these long-distance migrants move northwards through the Bolivian chaco and follow a corridor along the northern base of the Andes. The Apolo birds could pertain to one of two forms, of which the DNA and songs are currently under study (Abadie et al. in prep.).

\section{Saffron-billed Sparrow Arremon flavirostris}

A very common inhabitant of the understorey in the middle elevation of the valley. These records represent another considerable range extension from eastern La Paz department.

\section{Hooded Tanager Nemosia pileata}

A common nuclear species of mixed flocks in the mid-valley, where usually encountered in the upper forest strata. Small groups were encountered away from mixed flocks in open clearings. The species is known from most of northern Bolivia (Remsen and Traylor 1989) and was to be expected in La Paz department, for which this record represents the first.

\section{Chestnut-vented Conebill Conirostrum speciosum}

A common member of canopy mixed flocks throughout the valley; this species shares a similar known range in Bolivia to that of the Hooded Tanager and this record, the first for La Paz department, was to be expected.

\section{Conservation}

The dry forest along the Río Machariapo is imperiled by the planned La Paz Cobija road. While road construction is currently less than $40 \mathrm{~km}$ to the south- 
west of Apolo, another section from Apolo almost reaching Vilipiza (Figure 1) is complete. Indeed work on this section in 1992 was only halted owing to the onset of the wet season. It seems inevitable that the road will pass directly through the Machariapo valley along what is the present-day trail to Tuichi and on into tropical lowland forest along the Río Tuichi. Some land along the valley belongs to private owners, but much appears to be under dispute, and it is difficult therefore to say what the implications of the road will be. Flat land on the floodplain will undoubtedly be cleared and developed for agricultural purposes. One landowner promised minimal development but there may be no solution to the slash-and-burn tactics of invading settlers, now unfortunately a common sight in much of the upper tropical zone throughout the Andes.

If the road finally connects Cobija, the capital of Pando department on the Brazilian border, with La Paz, then the implications are severe for the whole of the lowland Amazonian forests of northern $\mathrm{La} \mathrm{Paz}$ department, which are currently the least disturbed in Bolivia. More tropical hardwoods could be extracted and at a greatly increased rate from that at present. Unfortunately, transportation would be through the Machariapo valley, which would cause a high level of disturbance.

While the completion of the road to Cobija will probably take several years, priorities for the present should be directed toward conserving the unique Machariapo valley. Bolivian and international conservation bodies should look hard at the opportunity of protecting at least part of the valley in light of the discovery of probable endemic plant taxa (Parker and Bailey 1991), the presence of a relict dry forest avifauna, and the discovery of the probable new antwren. Further field study should be conducted by ornithologists, as there is a possibility of other forms existing, and by biologists working in other fields, for the same reason.

\section{Acknowledgements}

I wish to express my thanks especially to Froilan Váldez for permission to visit Estancia San Isidro de Paquicha and for the logistical help given. I also thank Omar Rocha O. for permission to study specimens held in CBF and some early comments on range extensions in La Paz. Warm thanks also go to Ted Parker and Thomas Schulenberg for their useful comments on a draft of this paper.

\section{Appendix. Preliminary checklist: birds of Río Machariapo, La Paz department}

Taxonomy follows Remsen and Traylor (1989) with the exception of Picumnus albosquamatus following Sibley and Monroe (1990). Data codes are as follows:

Relative Abundance (R.A.)

C Common; recorded daily in numbers $>10$

F Fairly common; recorded daily, or almost daily with $<10$ individuals

$\mathrm{U}$ Uncommon; recorded once in three days

$\mathrm{R} \quad$ Rare; one or two records only

(nM) Northern migrant; from North America

(aM) Austral migrant; from the Southern Cone 
$x \quad$ Species recorded only on the Apolo Plateau, hence relative abundance not given due to time period.

Foraging Position (F.P.)

$\mathrm{T}$ Terrestrial

$\mathrm{U} \quad$ Understorey; to $4 \mathrm{~m}$ up

$\mathrm{M} \quad$ Mid-strata; $4 \mathrm{~m}$ to $\mathrm{c}$. 10-15 $\mathrm{m}$ up, depending on canopy height

$\mathrm{S} \quad$ Subcanopy/canopy; typically above $10-15 \mathrm{~m}$

A Aerial

Sociality (Soc.)

S Solitary, pairs or family groups

M Mixed species flocks

G Gregarious

Habitat (Hab.)

F Forest (dry)

E Edge; forest edge or clearings

P Plantations; inside dry forest coffee/mandarin

G Grassland and savanna; lowland or upland

S Scrub; low to chaparral-type woodland on the Apolo Plateau

$\mathrm{T}$ Town; in gardens or on buildings in Apolo

Evidence (Evid.)

Sp Specimen obtained

$N$ Netted and released; all photographed in the hand, biometrics and some blood samples taken

T Tape-recording made

P Photograph taken in wild state

$S \quad$ Identified visually or by voice

* New department record for La Paz (see Noteworthy records)

$+\quad$ Noteworthy record

\begin{tabular}{llllll}
\hline Species & R.A. & F.P. & Soc. & Hab. & Evid. \\
\hline TINAMIDAE & & & & & \\
Tinamus tao & $\mathrm{U}$ & $\mathrm{T}$ & $\mathrm{S}$ & $\mathrm{F}$ & $\mathrm{S}$ \\
Crypturellus undulatus & $\mathrm{F}$ & $\mathrm{T}$ & $\mathrm{S}$ & $\mathrm{F}$ & $\mathrm{T}$ \\
C. atrocapillus & $\mathrm{C}$ & $\mathrm{T}$ & $\mathrm{S}$ & $\mathrm{F}$ & $\mathrm{T}$ \\
C. tataupa & $\mathrm{C}$ & $\mathrm{T}$ & $\mathrm{S}$ & $\mathrm{F}$ & $\mathrm{S}$ \\
CATHARTIDAE & & & & & \\
Coragyps atratus & $\mathrm{U}$ & $\mathrm{A}$ & $\mathrm{S}, \mathrm{G}$ & $\mathrm{F}, \mathrm{E}, \mathrm{G}$ & $\mathrm{S}$ \\
Cathartes aura & $\mathrm{U}$ & $\mathrm{A}$ & $\mathrm{S}, \mathrm{G}$ & $\mathrm{F}, \mathrm{E}$ & $\mathrm{S}$ \\
ACCIPITRIDAE & & & & & \\
Buteo magnirostris & $\mathrm{U}$ & $\mathrm{M}, \mathrm{S}$ & $\mathrm{S}$ & $\mathrm{E}$ & $\mathrm{S}$ \\
$\begin{array}{l}\text { FALCONIDAE } \\
\text { Micrastur ruficollis }\end{array}$ & & & & & \\
Falco sparverius & $\mathrm{R}$ & $?$ & $\mathrm{~S}$ & $\mathrm{~F}$ & $\mathrm{~S}$ \\
F. peregrinus & $\mathrm{X}$ & $\mathrm{A}$ & $\mathrm{S}$ & $\mathrm{T}$ & $\mathrm{S}$ \\
CRACIDAE & $\mathrm{R}$ & $\mathrm{A}$ & $\mathrm{S}$ & $\mathrm{F}$ & $\mathrm{P}$ \\
Ortalis guttata & & & & & \\
& $\mathrm{F}$ & $?$ & $\mathrm{~S}$ & $\mathrm{~F}$ & $\mathrm{~S}$
\end{tabular}


COLUMBIDAE

Zenaida auriculata

Columbina picui

Leptotila verreauxi

L. megalura

$\begin{array}{lllll}x & \text { T } & \text { S, G } & \text { G } & \text { S } \\ x & \text { T } & \text { S, G } & \text { T,S } & \text { S } \\ \text { F } & \text { T } & \text { S } & \text { F,S } & \text { S } \\ \text { F } & \text { T } & \text { S } & \text { F } & \text { S }\end{array}$

PSITTACIDAE

Aratinga leucophthalmus

Pyrrhura sp.

Pionus menstruus

$\begin{array}{lllll}C & \text { S } & \text { G } & \text { F } & \text { S } \\ \text { C } & \text { S } & \text { G } & \text { F } & \text { S }+ \\ \text { F } & \text { M,S } & \text { S,G } & \text { F } & \text { P }\end{array}$

CUCULIDAE

Coccyzus erythropthalmus

Piaya cayana

Neomorphus geoffroyi

$\begin{array}{lllll}\mathrm{R}(\mathrm{nM}) & \mathrm{M}, \mathrm{S} & \mathrm{M} & \mathrm{E} & \mathrm{S} * \\ \mathrm{~F} & \mathrm{M}, \mathrm{S} & \mathrm{S}, \mathrm{M} & \mathrm{F}, \mathrm{E}, \mathrm{P} & \mathrm{S} \\ \mathrm{R} & \mathrm{T} & \mathrm{S} & \mathrm{F} & \mathrm{T}\end{array}$

STRIGIDAE

Otus guatemalae

$\mathrm{R}$

CAPRIMULGIDAE

Nyctidromus albicollis

TROCHILIDAE

Phaethornis sp.

Klais guimeti

TROGONIDAE

Trogon curucui

MOMOTIDAE

Momotus momota

BUCCONIDAE

Nystalus chacuru

GALBULIDAE

Galbula ruficauda

RAMPHASTIDAE

Pteroglossus castanotis

PICIDAE

Picumnus albosquamatus

Veniliornis affinis

Dryocopus lineatus

Campephilus melanoleucos

M,S S

F $\quad T^{*}$

F

A

$\mathrm{S}$

F,E $\quad \mathrm{S}$

DENDROCOLAPTIDAE

Sittasomus griseicapillus

Dendrocolaptes picumnus

Lepidocolaptes affinis

Campylorhampus trochilirostris

$\begin{array}{lllll}\mathrm{U} & \mathrm{U}, \mathrm{M} & \mathrm{S} & \mathrm{F} & \mathrm{S} \\ \mathrm{U} & \mathrm{U}, \mathrm{M} & \mathrm{S} & \mathrm{F}, \mathrm{E} & \mathrm{S}\end{array}$

U

M,S S,M F S

$\mathrm{F}$

M

S

F

$\mathrm{T}$

$x$

M

S

S

S

FURNARIIDAE

Poecilurus scutatus

Phacellodomus ruber

F

M,S S,M

E,P

N,T

U

M,S

G

E,P S

$\mathrm{F}$

R

U

\section{M}

$S, M$

F,E

N,T

$M, S$

$\mathrm{S}, \mathrm{M}$

F

$\mathrm{S}$

M,S S F,E S

Xenops minutus

$\begin{array}{lllll}\text { F } & \text { M } & \text { S,M } & \text { F,E,P } & \text { N } \\ \text { F } & \text { M } & \text { S,M } & \text { F } & \text { S } \\ \text { R } & \text { M } & \text { S,M } & \text { F } & \text { S } \\ \text { U } & \text { M } & \text { S,M } & \text { F } & \text { S } \\ & & & & \\ \text { C } & \text { U, T } & \text { S,M } & \text { F } & T^{*} \\ \text { x } & \text { U } & \text { S } & \text { S } & \text { S } \\ \text { F } & \text { S } & \text { M } & \text { F } & \text { S }\end{array}$


FORMICARIIDAE

\begin{tabular}{|c|c|c|c|c|c|}
\hline Taraba major & $\mathrm{F}$ & $\mathrm{U}$ & $S, M$ & $\mathrm{~F}, \mathrm{E}, \mathrm{P}$ & $\mathrm{N}, \mathrm{T}$ \\
\hline Thamnophilus palliatus & $\mathrm{U}$ & $\mathrm{U}$ & S,M & $\mathrm{E}, \mathrm{P}$ & $\mathrm{S}$ \\
\hline T. aroyae & $\mathrm{F}$ & $\mathrm{U}$ & S,M & $\mathrm{F}, \mathrm{E}$ & $\mathrm{Sp}$ \\
\hline Dysithamnus mentalis & $\mathrm{F}$ & $\mathrm{U}, \mathrm{M}$ & $S, M$ & $\mathrm{~F}, \mathrm{E}$ & $\mathrm{T}$ \\
\hline Myrmotherula longicauda & $\mathrm{F}$ & $M, S$ & M & $\mathrm{E}, \mathrm{P}$ & $\mathrm{T}$ \\
\hline Myrmotherula sp. & $\mathrm{R}$ & $\mathrm{U}$ & M & $\mathrm{F}$ & $S$ \\
\hline Herpsilochmus sp. & C & $\mathrm{U}, \mathrm{M}$ & $S, M$ & $\mathrm{~F}, \mathrm{E}, \mathrm{P}$ & $\mathrm{SpT}+$ \\
\hline Formicivora melanogaster & $\mathrm{C}$ & $\mathrm{U}, \mathrm{T}$ & $\mathrm{S}, \mathrm{M}$ & $\mathrm{F}, \mathrm{E}$ & $\mathrm{N}, \mathrm{T}^{*}$ \\
\hline Pyriglena leuconota & $\mathrm{R}$ & $\mathrm{U}$ & $\mathrm{G}, \mathrm{M}$ & $\mathrm{F}, \mathrm{E}$ & $S$ \\
\hline Chamaeza campanisona & $\mathrm{R}$ ? & $\mathrm{T}$ & $S$ & $\mathrm{~F}$ & $S$ \\
\hline \multicolumn{6}{|l|}{ TYRANNIDAE } \\
\hline Camptostoma obsoletum & $\mathrm{F}$ & $\mathrm{M}$ & $S, M$ & $\mathrm{~F}, \mathrm{E}$ & $S$ \\
\hline Myiopagis viridicata & $\mathrm{F}$ & $\mathrm{M}$ & S,M & $F, E$ & $\mathrm{~N}, \mathrm{~T}$ \\
\hline Elaenia albiceps & $\mathrm{R}(\mathrm{aM})$ & $\mathrm{M}$ & $S$ & $\mathrm{E}$ & $\mathrm{N}$ \\
\hline Leptopogon amaurocephalus & $\mathrm{F}$ & $\mathrm{M}$ & M & $\mathrm{F}, \mathrm{E}$ & $\mathrm{T}$ \\
\hline Corythopis torquata & $\mathrm{R}$ & $\mathrm{U}$ & $S$ & $\mathrm{~F}, \mathrm{P}$ & $\mathrm{T}$ \\
\hline Myiornis albiventer & $\mathrm{R}$ & $\mathrm{M}$ & S,M & $\mathrm{F}$ & $S$ \\
\hline Hemitriccus spodiops & $\mathrm{F}$ & $\mathrm{U}$ & $\mathrm{S}, \mathrm{M}$ & $\mathrm{F}$ & $\mathrm{T}$ \\
\hline H. margaritaceiventer & $\mathrm{C}$ & $\mathrm{U}, \mathrm{M}$ & S,M & $\mathrm{F}, \mathrm{E}, \mathrm{P}$ & $\mathrm{N}$ \\
\hline Tolmomyias sulphurescens & $\mathrm{F}$ & M & S,M & $\mathrm{F}, \mathrm{E}, \mathrm{P}$ & $\mathrm{N}, \mathrm{T}$ \\
\hline Contopus borealis & $\mathrm{U}(\mathrm{nM})$ & $\mathrm{M}, \mathrm{S}$ & $S$ & $\mathrm{E}$ & $S$ \\
\hline Empidonax traillii (alnorum) & $\mathrm{U}(\mathrm{nM})$ & M & $S$ & $\mathrm{E}, \mathrm{S}$ & $N^{*}$ \\
\hline Lathotriccus euleri & $\mathrm{R}$ & M & $S$ & $\mathrm{~F}$ & $\mathrm{~S}$ \\
\hline Casiornis rufa & $\mathrm{F}$ & $\mathrm{M}, \mathrm{c}$ & $S, M$ & $\mathrm{~F}$ & $\mathrm{P}$ \\
\hline Myiarchus cephalotes & $\mathrm{F}$ & $M, S$ & $S, M$ & $\mathrm{~F}, \mathrm{E}$ & S \\
\hline Megarynchus pitangua & $\mathrm{F}$ & $S$ & $S, M, G$ & $\mathrm{~F}, \mathrm{E}$ & $\mathrm{S}$ \\
\hline Myiozetetes similis & $\mathrm{R}$ & $\mathrm{M}$ & $\mathrm{S}$ & $\mathrm{E}, \mathrm{P}$ & $\mathrm{S}$ \\
\hline Myiodynastes maculatus & $\mathrm{R}$ & $M, S$ & M & $\mathrm{F}$ & $S$ \\
\hline Tyrannus melancholicus & $\mathrm{F}$ & $\mathrm{S}$ & $\mathrm{S}$ & $\mathrm{F}, \mathrm{E}, \mathrm{S}$ & $\mathrm{S}$ \\
\hline Pachyramphus polychopterus & $\mathrm{F}$ & $M, S$ & M & $\mathrm{F}$ & $\mathrm{S}$ \\
\hline P. marginatus & $\mathrm{F}$ & $M, S$ & M & $\mathrm{F}$ & $\mathrm{S}$ \\
\hline \multicolumn{6}{|l|}{ HIRUNDINIDAE } \\
\hline Notiochelidon cyanoleuca & $x$ & A & G & $\mathrm{T}$ & $\mathrm{S}$ \\
\hline \multicolumn{6}{|l|}{ TROGLODYTIDAE } \\
\hline Thryothorus genibarbis & C & $\mathrm{U}$ & $S$ & $\mathrm{~F}$ & $\mathrm{~T}$ \\
\hline Troglodytes aedon & $\mathrm{F}$ & $\mathrm{U}$ & $S$ & $\begin{array}{l}\text { S,F, } \\
\text { E,T }\end{array}$ & $\mathrm{S}$ \\
\hline \multicolumn{6}{|l|}{ TURDINAE } \\
\hline Catharus ustulatus & $\mathrm{R} ?(\mathrm{nM})$ & M & S,M & $F$ & $S$ \\
\hline \multicolumn{6}{|l|}{ CORVIDAE } \\
\hline Cyanocorax cyanomelas & $\mathrm{C}$ & M,S & $G, M$ & $\begin{array}{l}\text { F,T,E, } \\
\text { S.P }\end{array}$ & $\mathrm{S}$ \\
\hline \multicolumn{6}{|l|}{ VIREONIDAE } \\
\hline Cyclarhis gujanensis & $\mathrm{F}$ & M & $\mathrm{S}, \mathrm{M}$ & $\mathrm{F}, \mathrm{E}$ & $S$ \\
\hline Vireo olivaceus & $\mathrm{F}$ & $M, S$ & M & $\mathrm{F}$ & $S$ \\
\hline
\end{tabular}




\section{EMBERIZINAE}

Zonotrichia capensis

Ammodramus humeralis

A. aurifrons

Sporophila schistacea

S. ruficollis

Arremon flavirostris

CARDINALINAE

Saltator maximus

Cyanocompsa cyanoides

THRAUPINAE

Schistochlamys melanopis

Hemithraupis guira

Nemosia pileata

Lanio versicolor

Ramphocelus carbo

Thraupis sayaca

T. palmarum

Euphonia chlorotica

E. laniirostris

Tersina viridis

Coereba flaveola

PARULIDAE

Parula pitiayumi

Geothlypis aequinoctialis

Basileuterus bivittata

Phaeothlypis rivularis

Conirostrum speciosum

ICTERIDAE

Psarocolius decumanus

$P$. angustifrons

$\begin{array}{lllll}x & \text { U,T,M } & \text { S } & \text { T,S } & \text { S } \\ x & \text { U,T } & \text { S } & \text { GS } & \text { S } \\ \text { U } & \text { U } & \text { S } & \text { GE } & \text { T } \\ \text { R } & \text { M } & \text { S } & \text { E } & \text { S + } \\ \text { x(aM) } & \text { U } & \text { S } & \text { G } & \text { S } \\ \text { C } & \text { U } & \text { S,M } & \text { F,E } & \text { N,T }\end{array}$

$\begin{array}{lllll}R & M & M & P, E & S \\ U & U & S & F, E & S\end{array}$

C

$\mathrm{F}$

M

S

S S

F M,S

M

U

F

$\mathrm{S}$

$\mathrm{S}, \mathrm{G}, \mathrm{M}$

F,E S

$\mathrm{S}$

$\mathrm{M}$

F,E S*

M,S

$M, S$

$\mathrm{M}$

F S

M,S

$\mathrm{S}, \mathrm{M}$

$P, F, E \quad S$

U M,S

S,M

S,T

$\mathrm{E}, \mathrm{S}, \mathrm{T} \quad \mathrm{S}$

S,M F,E S

U

$\mathrm{M}, \mathrm{S}$

$S, M$

M,S

$G$

F,E S

$x$

$\mathrm{M}$

S,M

$S$

T, S S

$\begin{array}{lllll}\text { F } & \text { M,S } & \text { M } & \text { F,E } & \text { S } \\ \text { x } & \text { U } & \text { S } & \text { S } & \text { S } \\ \text { R } & \text { M } & \text { M } & \text { F,E } & \text { S } \\ \text { F } & \text { F } & \text { S } & \text { R } & \text { S } \\ \text { F } & \text { M,S } & \text { M } & \text { F,E } & \text { S }\end{array}$

C M,S G,M F,E,P S

C M,S G,M F,E T

\section{References}

Davis, T. J. and O'Neill, J. P. (1986) A new species of antwren (Formicariidae: Herpsilochmus) from Peru, with comments on the systematics of other members of the genus. Wilson Bull. 98: 337-352.

Fitzpatrick, J. W. and $\mathrm{O}^{\prime}$ Neill, J. P. (1979) A new tody-tyrant from northern Peru. Auk 96: $443-447$.

Fitzpatrick, J. W., Willard, D. E. and Terborgh, J. W. (1979) A new species of hummingbird from Peru. Wilson Bull. 91: 177-186.

Graves, G. R. and Weske, J. S. (1987) Tangara phillipsi, a new species of tanager from the Cerros del Sira, eastern Peru. Wilson Bull. 99: 1-6.

Hardy, J. W., Coffey, B. B., Jr., and Reynard, G. R. (1990) Voices of the New World owls. Gainsville, Florida: ARA Records.

Lowery, G. H. and $\mathrm{O}^{\prime}$ Neill, J. P. (1964) A new genus and species of tanager from Peru. Auk 81: 125-131.

Parker, T. A., III, and Bailey, B., eds. (1991) A biological assessment of the Alto Madidi region 
and adjacent areas of northwest Bolivia. Washington, D.C.: Conservation International (RAP Working Paper 1).

Pearman, M. and Abadie, E. I. (in prep.) Mesopotamia Grassland and Wetland Survey: conservation of threatened birds and habitat in north-east Argentina.

Pyle, P., Howell, S. N. G., Yunick, R. P. and DeSante, D. F. (1987) Identification guide to North American passerines. Bolinas, California: State Creek Press.

Remsen, J. V., Jr., and Traylor, M. A., Jr. (1989) An annotated list of the birds of Bolivia. Vermillion, South Dakota: Buteo Books.

Schulenberg, T. S. and Binford, L. C. (1985) A new species of tanager (Emberizidae: Thraupinae, Tangara) from southern Peru. Wilson Bull. 97: 413-420.

Sibley, C. G. and Monroe, B. L., Jr. (1990) Distribution and taxonomy of birds of the world. New Haven: Yale University Press.

MARK PEARMAN

58 Prospect Place, Wapping Wall, London E1 9TJ, U.K. 